\title{
Numerical Evaluation on the Different Shapes of Gravelly Sand Columns to Increase the Loading Capacity of Soft Clay
}

\author{
Sif Allah Meghzili ${ }^{1,2}$, Aziman Madun ${ }^{1,2, *}$, Saiful Azhar Ahmad Tajudin ${ }^{1,2}$, Mohd Fairus \\ Yusof $^{1,2}$, and Mohd Ashraf Mohamad Ismail $^{3}$ \\ ${ }^{1}$ Universiti Tun Hussein Onn Malaysia, Batu Pahat, Johor, Malaysia \\ ${ }^{2}$ Research Centre for Soft Soil, University of Tun Hussein Onn, Malaysia \\ ${ }^{3}$ University Sains Malaysia
}

\begin{abstract}
Improvement on soft clay by the installation of stone column is one of the most popular methods followed worldwide. Different analytical and numerical solutions have already been developed for understanding the load transfer mechanism of soft soil reinforced with stone column. This study investigated a bearing capacity of the gravelly sand column, installed in soft clay bed at $15 \mathrm{kpa}$ of undrained shear strength. The column variable of length and diameter ratio at 7,8 and 9 were evaluated. On top of that, the combination of two diameters in single column was tested and the uniform diameter was used as a control. In the numerical analysis, Mohrcoulomb model was adopted in the idealization of the behaviour of the gravelly sand column and soft clay materials. The results revealed that the optimum design that gave the highest loading capacity of the combination $11=12$ of column diameter was the length and diameter ratio of 8 .
\end{abstract}

\section{Introduction}

There are a numerous amount of methods for ground improvement were developed throughout the world. Amongst the wide range of ground improvement methods is stone column, which is often considered as cost-effective and environmentally friendly comparing to other types of stiffening column techniques [1]. The stone column technique of ground improvement has been proven to be successful in improving slope stability of both embankments and natural slopes, via increasing ground bearing capacity and accelerating the period of settlement. The stone column length has been always designed to be reached at stiff layer [2]. In cases of very deep weak soil, which has shear strength below $30 \mathrm{kPa}$, the application of stone column is not economics [3]. In recent years, the stiffening column technique has been adopted the floating stone column, when the soft ground is too deep. The bearing capacity was remained constant for the floating stone column at length to diameter ratio (L/D) of 10 [4-6]. According to Sivakumar et al [7] and Tekin and Ergun [8], the effective length to diameter ratio of the column was between 7 and 9. However, longer

\footnotetext{
*Corresponding author: aziman@uthm.edu.my
} 
column may be needed to reduce the settlement. The ultimate bearing capacity, settlement, and general stability are the parameters to identify the stone column performance.

Numerical analysis enables the resolution of complex problems where the combination of the analytical solutions and experimental measurements can be established. The numerical models were developed using the finite element analysis software such as plaxis. Regardless of the development of more selected constitutive models for soil, the MohrCoulomb yield criterion remains a popular choice for geotechnical analysis due to its ease and simplicity to be used by practising engineers [9]. However, Mohr-Coulomb model is the most common constitutive laws used in finite element methods [10]. Al-Saidi [11] studied the behaviour of stone column using the axisymmetric single stone column using (unit cell) concept in the finite element programs. The result showed the failure depth, where the bulging zone occurred between 2 to 3 times the diameter. Gunduz [12] used the plaxis software and adopted a hardening soil and Mohr-coulomb models to analyse the deformation for 50 years period. Both model analyses showed similar results. Shien [13] used Mohr-coulomb model which indicated that the plastic zone was at 0.6 times of the length. Mats [14] indicated that the Mohr-Coulomb material model is inadequate to predict the primary consolidation of soft clay, and thus needs to refer to actual deformation measurements. Meanwhile, Ruben [15] investigated the behaviour of single stone columns via adopting Mohr-Coulomb and modifying Drucker-Prager models which resulted the column diameter influenced the loading capacity and the optimum length to diameter ratio was between 7 and 9. Therefore, this study has considered the design of the floating stone column at length to diameter ratio between 7 and 9. On top of that, the combination of two diameters in single column was tested and the uniform diameter was used as a control. In the numerical analysis, Mohr-coulomb drained and undrained model materials were adopted in the idealization of the behaviour of the gravelly sand column and soft clay materials.

\section{Methodology}

The compression modelling was performed using the plaxis 2-dimensional program. The model was based on the scaled-down at 25 times similar to Kelly [5]. The model of $84 \mathrm{~mm}$ wide and $450 \mathrm{~mm}$ high represents the unit cell (De) containing a soft clay as shown in Fig 1(a). It was deemed to represent a field scenario where gravelly sand column was installed in a triangular pattern $(\mathrm{De}=1.05 \mathrm{~S})$ where the spacing $(\mathrm{S})$ at $80 \mathrm{~mm}$. The uniform diameter of the column as a control shape was installed at the centre of the soft clay with a diameter (D) at $44 \mathrm{~mm}$ to achieve a replacement ratio in the average (as) between 0.25 and 0.50 .

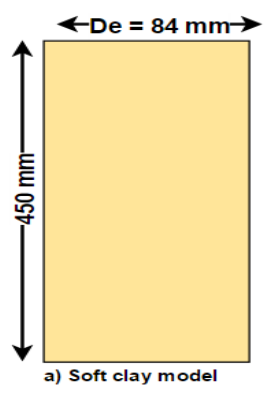

Fig. 1. Geometry of models
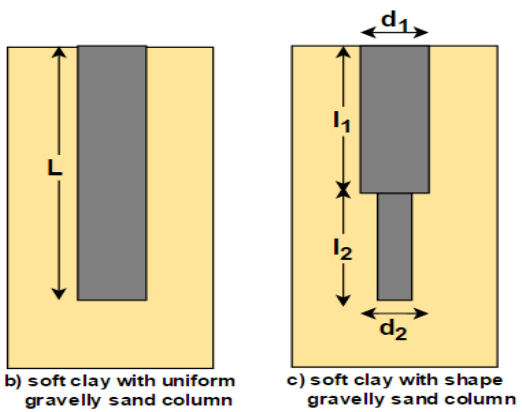
The various lengths (L) of the column were adopted at 308, 352 and $396 \mathrm{~mm}$ according to the ratio of length and diameter (L/D) between 7, 8 and 9 respectively as shown in Fig. 1(b). The combination of two column diameters ( $\mathrm{d} 1$ and $\mathrm{d} 2$ ) and lengths (11 and 12) was installed at the centre of the soft clay as shown in Fig. 1 (c). The first diameter (d1) is similar with control shape and for the second column diameter (d2) is smaller at $44 \mathrm{~mm}$ and $20 \mathrm{~mm}$ respectively. There were 9 variables adopted at first diameter column lengths (11) of 102.6, 154, 205.4, 117.4, 176, 234.6, 132, 198, $264 \mathrm{~mm}$ and second diameter column lengths (12) at 205.4, 154, 102.6, 234.6, 176, 117.4, 264, 198, $132 \mathrm{~mm}$. Table 1 and 2 summarize the parameters adopted in the numerical analysis.

Table 1. Uniform column diameter

\begin{tabular}{|c|c|c|c|}
\hline No & Length (L), mm & Diameter (D), mm & Ratio (L:D) \\
\hline $\mathbf{1}$ & 308 & \multirow{3}{*}{44} & $7: 1$ \\
\hline $\mathbf{2}$ & 352 & & $8: 1$ \\
\hline $\mathbf{3}$ & 396 & & $9: 1$ \\
\cline { 1 - 1 } & & & \\
\end{tabular}

Table 2. Combination of 2 columns diameter

\begin{tabular}{|c|c|c|c|c|c|c|c|}
\hline No & $\begin{array}{l}\text { Length } \\
\text { (11), mm }\end{array}$ & $\begin{array}{c}\text { Length } \\
\text { (12), } \\
\text { mm }\end{array}$ & $\begin{array}{l}\text { Ratio } \\
\text { (11:12) }\end{array}$ & $\begin{array}{c}\text { Total } \\
\text { length, }(L) \\
\text { mm }\end{array}$ & $\begin{array}{l}\text { Diameter } \\
\text { (d1), } \mathrm{mm}\end{array}$ & $\begin{array}{l}\text { Diameter } \\
\text { (d2), mm }\end{array}$ & $\begin{array}{l}\text { Ratio } \\
\text { (L:d1) }\end{array}$ \\
\hline 1 & 102.6 & 205.4 & $1: 2$ & \multirow{3}{*}{308} & \multirow{9}{*}{44} & \multirow{9}{*}{20} & \multirow{3}{*}{$7: 1$} \\
\hline 2 & 154 & 154 & $1: 1$ & & & & \\
\hline 3 & 205.4 & 102.6 & $2: 1$ & & & & \\
\hline 4 & 117.4 & 234.6 & $1: 2$ & \multirow{3}{*}{352} & & & \multirow{3}{*}{$8: 1$} \\
\hline 5 & 176 & 176 & $1: 1$ & & & & \\
\hline 6 & 234.6 & 117.4 & $2: 1$ & & & & \\
\hline 7 & 132 & 264 & $1: 2$ & \multirow{3}{*}{396} & & & \multirow{3}{*}{$9: 1$} \\
\hline 8 & 198 & 198 & $1: 1$ & & & & \\
\hline 9 & 264 & 132 & $2: 1$ & & & & \\
\hline
\end{tabular}

\section{Material properties}

Kaolin from Associated Kaolin Industries was the main material used to form a soft clay bed. This material was used to ensure a high degree of sample control and reduce variability throughout the test program. Its properties were determined during the laboratory tests as summarized in Table 3. The material for constructing the column was obtained by sieving a fine quarry aggregate in the laboratory. The suitable grain sizes were based on the scaled-down prototype grain diameter at 25 . For this study, a prototype of the bottom feed technique of constructing sand columns was used with a typical grain size diameter of 10 to $40 \mathrm{~mm}$ and thus, the scaled-down grain size diameter was between 0.4 $\mathrm{mm}$ and $1.6 \mathrm{~mm}$. Properties of the gravelly sand were determined during the laboratory tests and summarized in Table 3.

\section{Constitutive model}

The Mohr - coulomb model is widely used in finite element analysis of geotechnical applications due to its simplicity and sufficient accuracy. The Mohr-coulomb model for drained and undrained condition was adopted to model the behaviour of the gravelly sand and soft clay materials respectively. Meanwhile, an Elasto-perfectly plastic behaviour with 
the Mohr-coulomb failure criterion was adopted for the material response under loading conditions. An elasto-perfectly plastic behaviour with the Mohr-Coulomb failure criterion was adopted for the material response under loading conditions. In terms of the principal stresses ( $\sigma 1$ and $\sigma 3)$, the failure envelope of the Mohr-Coulomb model is defined using (1).

$$
(\sigma 1-\sigma 3)+(\sigma 1+\sigma 3) \sin \varphi-2 c \cos \varphi=0
$$

where $\mathrm{c}$ and $\varphi$ are the cohesion and the angle of internal friction of the material respectively.

Table 3. Properties of soft clay and gravelly sand materials

\begin{tabular}{|c|c|c|c|}
\hline Properties & Unit & Soft clay & Gravelly sand \\
\hline Specific gravity & --- & 2.65 & 2.70 \\
\hline Moisture content & $\%$ & 42 & 9 \\
\hline Undrained shear strength & $\mathrm{kPa}$ & 15 & $\mathrm{~N} . \mathrm{G}$ \\
\hline Cohesion & $\mathrm{N} / \mathrm{mm} 2$ & 0.00887 & 0.000376 \\
\hline Angle of internal friction & $\mathrm{o}$ & 31.2 & 47.9 \\
\hline Dilatancy angle & $\mathrm{o}$ & 10.4 & 15.97 \\
\hline Permeability & $\mathrm{mm} / \mathrm{s}$ & $7 \mathrm{e}^{-6}$ & 0.012 \\
\hline Young modulus & $\mathrm{N} / \mathrm{mm} 2$ & 1.8 & 40 \\
\hline Poisson ratio & --- & 0.35 & 0.30 \\
\hline Unit weight saturation & $\mathrm{N} / \mathrm{mm} 3$ & $1.738 \mathrm{e}^{-5}$ & $2.138 \mathrm{e}^{-5}$ \\
\hline Unit weight unsaturation & $\mathrm{N} / \mathrm{mm} 3$ & $1.224 \mathrm{e}^{-5}$ & $2.04 \mathrm{e}^{-5}$ \\
\hline
\end{tabular}

\section{Finite element analysis}

\subsection{Program used}

Plaxis as the most used software packages in geotechnical engineering was employed for finite element analysis. Plaxis $2 \mathrm{D}$ is a two dimensional finite element program interface but currently restricted to 2D plane strain and axisymmetric problems. The program can deal with undrained and drained consolidation analysis of two dimensions (with axisymmetric loading).

\subsection{Finite element geometry, boundary conditions}

The problem of axially loaded sand column surrounded with soft clay is an axisymmetric one, because the materials are homogenous. Axisymmetric finite element analysis was carried out for the assessment of the load settlement of the soft clay and gravelly sand column. Due to symmetry, only half of the axisymmetric problem is considered. The boundary conditions of the axisymmetric problem domain are shear free with no radial movement at the lateral sides and prevent the bottom boundary from both radial and vertical movements as shown in Fig. 2. Fifteen nodes elements are used to model the soft clay and gravelly sand column. An example of the domain meshes generated from the analyses is shown in Fig. 3. 


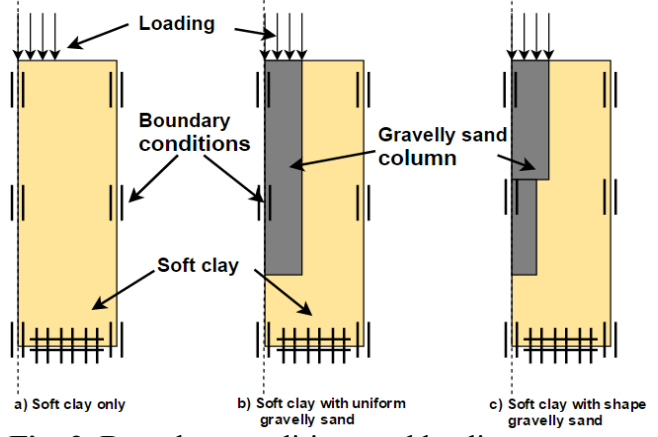

Fig. 2. Boundary conditions and loading
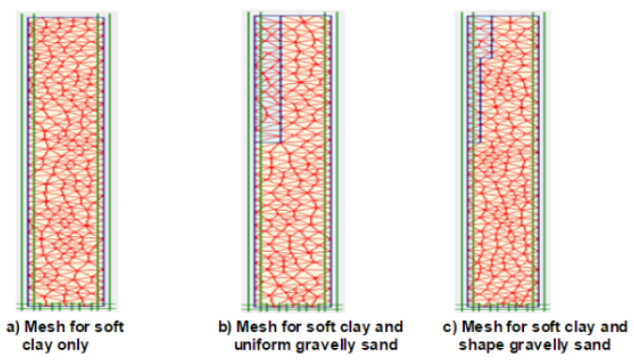

Fig. 3. Mesh of the models

\section{Results and discussion}

Fig. 4 shows the relation between the load and the displacement for three cases of soft clay only, uniform column diameter, and the combination of two column diameters (11 and 12) when the ratio of length and diameter $(\mathrm{L} / \mathrm{D})$ is 7.

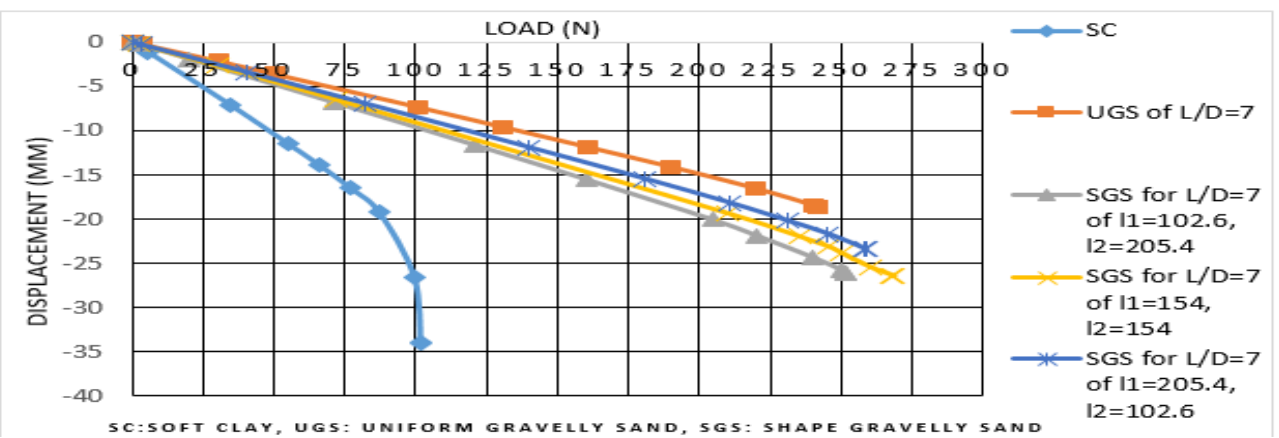

Fig. 4. Load vs. displacement for column at ratio $(\mathrm{L} / \mathrm{D}=7) 7: 1$

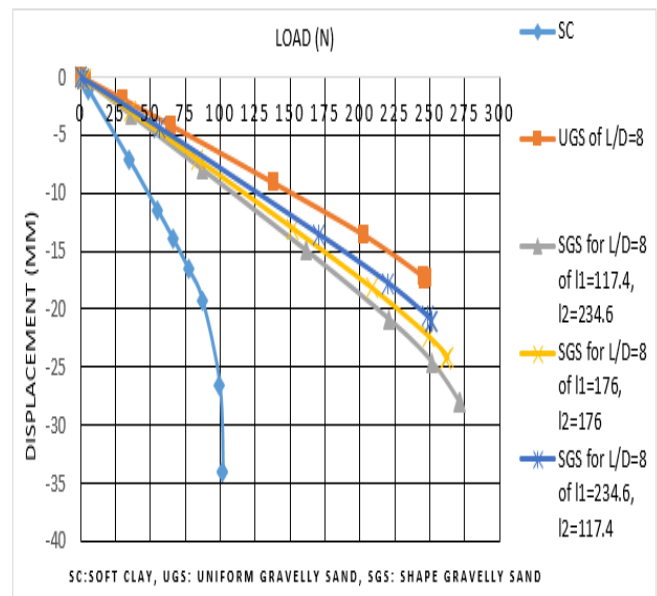

Fig. 5. Load vs. displacement for the column at ratio $(\mathrm{L} / \mathrm{D})$ 8:1

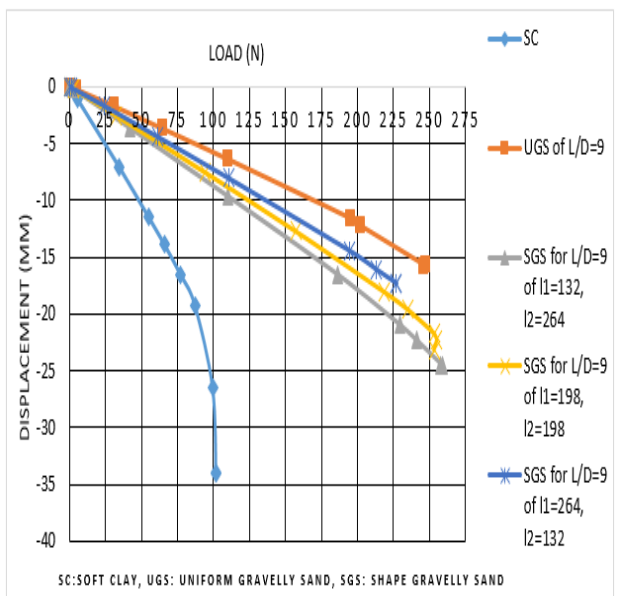

Fig. 6. Load vs. displacement for the column at ratio (L/D) 9:1 
The loading capacity increased more than twice with the column installation at uniform and a combination of two diameters. The highest loading capacity for column length at $308 \mathrm{~mm}$ was the uniform column diameter and a combination of two column diameters (11 and 12) at ratio $1: 1$ of $268.506 \mathrm{~N}$.

In the case of the column length at $352 \mathrm{~mm}$ and diameter $44 \mathrm{~mm}$ at a ratio (L/D) 8:1 as shown in Fig. 5, the loading capacity increased more than twice with the column installation at uniform and a combination of two diameters. The highest loading capacity for column length of $352 \mathrm{~mm}$ was the combination of two column diameters (11 and 12) at ratio $1: 2$ of $271.543 \mathrm{~N}$.

In the case of the column length at $396 \mathrm{~mm}$ and diameter $44 \mathrm{~mm}$ at a ratio (L/D) 9:1 as shown in Fig. 6, the loading capacity increased more than twice with the column installation at uniform and a combination of two diameters. The highest loading capacity for column length of $396 \mathrm{~mm}$ was the combination of two column diameters (11 and 12) at ratio $1: 2$ of $258.865 \mathrm{~N}$.

\section{Conclusion}

From the finite element analysis, the following conclusions can be drawn:

- The loading capacity without and with the column is more than twice, indicating that column is able to improve the bearing capacity of soft clay.

- The loading capacity of the uniform column and the combination of two column diameters are comparatively equal. However, in many cases, the highest loading capacity was a combination of two column diameters.

- The column ratio length and diameter $(\mathrm{L} / \mathrm{D}=8)$ and the combination of two column diameters $(11$ and 12$)$ at ratio $1: 2(\mathrm{~L} / \mathrm{D}=8$ of $11=176,12=176)$ have the highest loading capacity of $271.543 \mathrm{~N}$.

- $\quad$ There is unbeneficial to increase the length to diameter ratio more than 8 .

The combination of two column diameters, where the larger column diameter at the top is practical to be implemented and able to reduce the volume of aggregate to build the column. It is recommended to explore the laboratory and numerical modelling of bulging and punching for the different column diameters.

The authors would like to thank the University Tun Hussein Onn Malaysia (UTHM), the Office for Research, Innovation, Commercialization and Consultancy Management (ORICC) for their financial support on GIPS phase 1/2015 vot. U270.

\section{References}

[1] E. Venere, Ground-improvement methods might protect against earthquakes, Purdue University News, (March 19, 2014)

[2] H.J. Priebe, The design of vibro replacement, Proceedings of the Institution of Civil Engineers, Ground engineering, Technical paper GT 037-13 E 31-37, (1995)

[3] A. Salahi, H. Niroumand, K.A. Kassim, Evaluation of stone columns versus liquefaction phenomenon, Department of Civil Engineering, Faculty of Engineering, Islamic A. University, Tehran, Iran, (2015)

[4] J.A Black, V. Sivakumar, M.R Madhav, G.A Hamill, Reinforced stone columns in weak deposits laboratory model study, Journal of Geotechnical and Geoenvironmental Engineering, 133(9), 1154-1161, (2007)

[5] K. Micheál, Numerical modelling of small groups of stone columns, College of Engineering and Informatics, National University of Ireland, Galway, (2012) 
[6] P. Kelly, Soil structure interaction and group mechanics of vibrated stone column foundation, Department of civil and structural engineering, University of Sheffield, (2014)

[7] V. Sivakumar, D. Glynn, J.A Black, M. Neill, A laboratory model study of the performance of vibrated stone columns in soft clay, Proceedings 14th European Conference on Soil Mechanics and Geotechnical Engineering, Madrid, (2007)

[8] M. Tekin, M.U. Ergun, A model study of strains under footings supported by floating and end-bearing granular columns, 18th ICSMGE, Paris, (2013)

[9] A.J. Abbo , A.V. Lyamin, S.W. Sloan, J.P. Hambleton, A C2 continuous approximation to the Mohr-Coulomb yield surface centre for geotechnical and materials modelling, University of Newcastle, Callaghan, (2011)

[10] H.S. Yu, A closed-form solution of stiffness matrix for Tresca and Mohr-Coulomb plasticity models, The University of Newcastle, Australia, (2003)

[11] A.A. Al-Saidi, The use of stone columns to improve soft soils, MSc Thesis, University of Baghdad, Iraq, (2000)

[12] B. Gunduz, Analysis of settlements of test embankments during 50 years - A Comparison between field measurements and numerical analysis, Lund University, Sweden, (2010)

[13] N.K. Shien, Numerical study of floating stone columns, National University of Singapore, Singapore, (2013)

[14] M. Kahlström, Plaxis 2D comparison of Mohr-Coulomb and soft soil material models, Luleå University of Technology, Sweden, (2013)

[15] R.A. Gnandji, Experimental and numerical analyses of the behavior of rammed stone columns installed in a South African Soft Soil, University of Cape Town, South Africa, (2014). 